\title{
Third generation biohydrogen production by Clostridium butyricum and adapted mixed cultures from Scenedesmus obliquus microalga biomass
}

\author{
Joana Ortigueira ${ }^{1}$, Luís Alves ${ }^{1}$, Luísa Gouveia ${ }^{1}$, Patrícia Moura* \\ Unidade de Bioenergia, Laboratório Nacional de Energia e Geologia, Estrada do Paço do Lumiar, 1649-038 Lisboa, Portugal
}

\section{H I G H L I G H T S}

- A mixed culture and C. butyricum were used to ferment dried and ground S. obliquus biomass.

- The best adapted mixed culture LE37 produces $1.52 \mathrm{~mol} \mathrm{H}_{2} / \mathrm{mol}$ from $50 \mathrm{~g} / \mathrm{L}$ of dried and ground S. obliquus.

- C. butyricum produces $116.3 \mathrm{~mL} \mathrm{H}_{2} / \mathrm{g}$ alga vs, attaining a $\mathrm{H}_{2}$ yield of $2.74 \mathrm{~mol} / \mathrm{mol}$.

- The biogas produced by $C$. butyricum has the highest purity, $\mathrm{H}_{2} / \mathrm{CO}_{2}(\mathrm{v} / \mathrm{v})$ of 1.7 .

\section{A R T I C L E I N F O}

\section{Article history:}

Received 21 April 2014

Received in revised form 26 January 2015

Accepted 22 February 2015

Available online 4 March 2015

\section{Keywords:}

Biohydrogen

Scenedesmus obliquus

Clostridium butyricum

Dark fermentation

Microalgal biomass

\begin{abstract}
A B S T R A C T
Scenedesmus obliquus biomass was used as a feedstock for comparing the biological production of hydrogen by two different types of anaerobic cultures: a heat-treated mixed culture from a wastewater treatment plant and Clostridium butyricum DSM 10702. The influence of the incubation temperature and the carbon source composition were evaluated in order to select the best production profile according to the characteristics of the microalgal biomass. C. butyricum showed a clear preference for monomeric sugars and starch, the latter being the major storage compound in microalgae. The highest $\mathrm{H}_{2}$ production reached by this strain from starch was $468 \mathrm{~mL} / \mathrm{g}$, whereas the mixed culture incubated at $37^{\circ} \mathrm{C}$ (LE37) produced $241 \mathrm{~mL} / \mathrm{g}$. When the mixed culture was incubated at $58^{\circ} \mathrm{C}$ (LE58), a significant increase in the $\mathrm{H}_{2}$ production occurred when xylose and xylan were used as carbon and energy source. The highest $\mathrm{H}_{2}$ yield reached by the LE37 culture or in co-culture with $C$. butyricum was 1.52 and $2.01 \mathrm{~mol} / \mathrm{mol}$ of glucose equivalents, respectively. However, the ratio $\mathrm{H}_{2} / \mathrm{CO}_{2}(\mathrm{v} / \mathrm{v})$ of the biogas produced in both cases was always lower than the one produced by the pure strain. In kinetic assays, $C$. butyricum attained $153.9 \mathrm{~mL} \mathrm{H}_{2} / \mathrm{L} \mathrm{h}$ from S. obliquus biomass within the first $24 \mathrm{~h}$ of incubation, with a $\mathrm{H}_{2}$ yield of $2.74 \mathrm{~mol} /$ mol of glucose equivalents. $\mathrm{H}_{2}$ production was accompanied mainly by acetate and butyrate as coproducts. In summary, $C$. butyricum demonstrated a clear supremacy for third generation $\mathrm{bioH}_{2}$ production from S. obliquus biomass.
\end{abstract}

(c) 2015 Elsevier Ltd. All rights reserved.

\section{Introduction}

Traditionally, large-scale hydrogen $\left(\mathrm{H}_{2}\right)$ is produced through steam reforming of natural gas [1]. This process involves the conversion of methane and water into carbon dioxide $\left(\mathrm{CO}_{2}\right)$ and molecular hydrogen at high temperature. $\mathrm{H}_{2}$ can also be obtained through electrolysis of water and thermocatalytic reformation of other $\mathrm{H}_{2}$ containing organic compounds [2]. Both are polluting and expensive processes [3]. Biological hydrogen $\left(\mathrm{bioH}_{2}\right)$ can be produced mainly by two routes: photobiologically and by fermentative processes

\footnotetext{
* Corresponding author. Tel.: +351 210924600; fax: +351217163636.

E-mail address: patricia.moura@lneg.pt (P. Moura).

1 Tel: +351 210924600; fax: +351217163636
}

(photofermentation and dark fermentation) [4]. The first one is based on the uptake of $\mathrm{CO}_{2}$ or other organic substrates and water by photosynthetic organisms. Its major drawbacks are the requirement of a constant light source supply and the low yields of the overall process [5]. Dark fermentation consists in the conversion of sugars into $\mathrm{H}_{2}, \mathrm{CO}_{2}$ and organic acids by microorganisms, through the acidogenic pathway. Theoretically, any sugar-containing biomass can be used as a feedstock [6] and if the chosen biomass is readily available and lost-cost, the appeal of the process could be increased.

Microalgae could meet these requirements as they have the capability to absorb solar energy and $\mathrm{CO}_{2}$ and convert it into chemicals; being able to store them as either natural oil, primary subject for biodiesel production, or other carbon storage 